Mathematical Programming 10 (1976) 413.

North-Holland Publishing Company

\title{
NOTICE
}

\section{THE MATHEMATICAL PROGRAMMING SOCIETY}

The Mathematical Programming Society was established in 1971 as an international organization dedicated to the development of the applications, computational methods, and theory of mathematical programming. The Society is now the principal sponsor of the International Symposia on Mathematical Programming. In addition to its journal, MATHEMATICAL PROGRAMMING, the Society issues a series called MATHEMATICAL PROGRAMMING STUDIES.

The Society is governed by an elected Council. Membership, financial records and other administrative functions are handled by its Secretariat, located at the permanent offices of the International Statistical Institute in The Netherlands.

The journal MATHEMATICAL PROGRAMMING appears in two volumes per year, three issues per volume and MATHEMATICAL PROGRAMMING STUDIES in three numbers per year. Subscriptions for personal use are handled by the Society. (Institutional subscriptions are handled by the North-Holland Publishing Company.) Individuals who join the Society during 1976 will receive volumes 10 and 11 of the journal and may, in addition, subscribe to the serial edition of the STUDIES.

To join the Society, please use the attached form.

\section{APPLICATION FOR MEMBERSHIP}

Mail to: MATHEMATICAL PROGRAMMING SOCIETY

c/o International Statistical Institute

428 Prinses Beatrixlaan

Voorburg, The Netherlands

Cheques or money orders should be made payable to The Mathematical Programming Society in one of the currencies indicated below.

$\square$ I wish to enroll as a member of the Society. My dues payment for 1976, which covers subscription to volumes 10 and 11 of MATHEMATICAL PROGRAMMING is enclosed: Dfl 83 (or $\$ 30.00$ or $£ 15.00$ or Sw.Fr. 83.00 or FF 138.00 or DM 81.00 ).

- As a member of the Society I wish to subscribe to the serial edition of the series MATHEMATICAL PROGRAMMING STUDIES (Nos. 7, 8 and 9) in 1976. Payment is enclosed. Dfl. 43 (or $\$ 16.00$ or $£ 7.75$ or Sw.Fr. 43.00 or FF 72.00 or DM 42.00 ).

My subscription(s) is (are) for my personal use and not for the benefit of any library or other institution.

Name (printed): Signature:

Mailing address (please print): 